\title{
Expression of p53 and p21 in bladder carcinoma of Iraqi patients
}

\author{
Rawaa Al Chalabi, ${ }^{1}$ Shahlaa M. Salih, ${ }^{1}$ Sajid Saad, ${ }^{2}$ Hayder Jawad ${ }^{2}$ \\ ${ }^{1}$ College of Biotechnology, Al-Nahrain University, Baghdad; ${ }^{2}$ Al-Yrmook Teaching Hospital, Baghdad, Iraq
}

\begin{abstract}
Bladder cancer is an abnormal cellular multiplication without control arising from the urinary bladder urothelium. Cells cycle is a strictly controlled process regulated by protein complexes composed of cyclins and cyclin-dependent kinases and also by several tumor suppressor gene protein products acting at the Go/G1 checkpoint of the cell-cycle. This study was designed to evaluate the frequency of p53 and p 21 expression as biomarkers to monitor the disease and compare the results with those of others. Seventy-three tumors with different stages and grades were collected from patients with bladder carcinoma and ten normal bladder biopsies from forensic autopsy. Sections were immunohistochemically stained for $\mathrm{p} 53$ and $\mathrm{p} 21$. Results revealed that $\mathrm{p} 53$ positive immune reactivity was observed in $(57.5 \%)$ which were exclusively nuclear and no immune reactivity detectable in $(42.5 \%)$ of tumors, while all normal tissues expressed negative patterns. Positive immune staining of p21 was recorded in $(69.5 \%)$ and negative p21 immune staining was recorded in $22(31.1 \%)$, as well as ten normal urothelium. Statistically p53 and p 21 over-expression was significantly related to stage and grade of tumors $(\mathrm{P}<0.05)$.
\end{abstract}

Correspondence: Rawaa Al Chalabi, College of Biotechnology, AlNahrain University, Baghdad, Iraq.

E-mail: RawaaAlChalabi_1984@yahoo.com

Key words: Urinary bladder cancer; p53; p21; Immunohistochemistry.

Contributions: RAC, researcher and corresponding author;

SMS: supervisor; SS, consultant pathologist; HJ, consultant urologist.

Conflict of interest: the authors declare no potential conflict of interest.

Funding: none.

Received for publication: 5 August 2018.

Revision received: 8 April 2019.

Accepted for publication: 21 April 2019.

CC Copyright R. Al Chalabi et al., 2019

Licensee PAGEPress, Italy

Journal of Biological Research 2019; $92: 7742$

doi:10.4081/jbr.2019.7742

This article is distributed under the terms of the Creative Commons Attribution Noncommercial License (by-nc 4.0) which permits any noncommercial use, distribution, and reproduction in any medium, provided the original author(s) and source are credited.

\section{Introduction}

Bladder cancer is the most common cancer in the upper urinary tracts, which has the highest rate of any malignancy. In Iraq, the incidence of bladder cancer is the fourth common type of cancer in men and eighth one in women. More than $90 \%$ of bladder cancers start from the urothelium known as urothelial or transitional cell carcinoma (TCC) while squamous cell carcinoma and adenocarcinoma are rare types. Cells of bladder carcinoma can spread through the blood and lymph vessels, attach to other tissues then grow to form new tumors, thus characterized by rapid progression from noninvasive to invasive stage. The incidence and mortality rates vary among the countries because of the differences of the risk factors and the availability of treatments. ${ }^{1-3}$

p53 is a tumor suppressor protein. It regulates the cell cycle, apoptosis and is involved in many cellular activities such as metabolism, antioxidant response, and DNA repair. The tumor suppressor gene has been located on the chromosome17p13, which encodes wild type p53 protein that consists of 393 amino acids, which described as the guardian of the genome, because of its role in the conserving stability by preventing genome mutation and tumor development. Tumor's defective p53 could allow abnormal cells to proliferate, resulting in cancer. As many as $50 \%$ of all human tumors contain p53 mutants., 4 Under usual conditions, p53 is expressed at an extremely low level, tightly suppressed in the normal cells by MDM2 (mouse double minute 2 homolog also known as E3 ubiquitin-protein ligase MDM2). Upon DNA damage, p53 is induced to accumulate in the cell nucleus through post-transnational modifications such as phosphorylation and acetylation. These modifications convert p53 to an active form by dissociation of MDM2. Effective p53 turns activate an appropriate set of its target genes to induce cell cycle arrest and/or apoptosis, which is dependent on the magnitude and sites of DNA damage. 6,7

p53 protein enhances another gene to produce a protein called p21 that interacts with cell division stimulating protein cyclindependent kinase 2 (CDK2), when p21 complexes with cdk2, the cell unable to pass through to the next stage of cell division. ${ }^{8-10} \mathrm{p} 21$ is recognized as the cyclin dependent kinase inhibitor, encoded by the CDKN1A gene located on chromosome 6p21.2 in humans. It facilitates cell cycle arrest by interaction with different stimuli and transition factors such as $\mathrm{p} 53$, which acts as a regulator of cell cycle progression by interacting with proliferating cell nuclear antigen, DNA polymerase accessory factor and plays a regulatory role in $\mathrm{S}$ phase DNA replication, DNA damage repair. ${ }^{11,12}$ Various stress stimuli and p53 protein responsible for activation of the apoptotic protein p21 and cause alteration in the checkpoints which led to arrest the cell cycle at G1 and G2 phases by binding and inhibiting the complexes of CDK and cyclin. ${ }^{13,14}$ p21 is sometime expressed without being induced by $\mathrm{p} 53$. Kind of induction plays a big role in p53 independent differentiation. Expression of p21 is mainly 
dependent on the stimulus provided and the type of the cell. ${ }^{15}$ p21 was expressed in a variety of human malignancies and correlated with tumor progression and a poor prognosis in various carcinomas. Expression of the mutant gene of $\mathrm{p} 21$ has been reported to be associated with progression of bladder carcinoma. ${ }^{16,17}$ This study was aimed to investigate the pathological significance and prognostic value of p53 and p21 in bladder cancer.

\section{Materials and Methods}

Seventy-three biopsies have been collected from urinary bladder cancer (UBC) patients after cystoscopy surgery, 60 male and 13 female with an average age 65.2 years and a range of (43 to 85) years, 32 patients had UBC and 30 healthy control. Subjects are collected through the period from March 2014 to the November 2014. They attended to the Urology Unit at Al-Yarmook and AlJabchi Hospitals. The tumors were graded as low or high on the basis of World Health Organization (WHO) classification criteria. While ten normal bladder biopsies have been collected from forensic autopsy.

\section{Immunohistochemical staining}

Immunohistochemically staining was performed by using labeled streptavidin biotin immune staining method. Briefly, 5-mm thick sections were deparaffinized and rehydrated. Most formalin fixed tissue requires an antigen retrieval step before immune staining. Antigen retrieval was performed by using the Tris EDTA buffer $\mathrm{pH}=9$ for $\mathrm{p} 53$ and Sodium Citrate buffer $\mathrm{pH}=6$ for $\mathrm{p} 21$, then placed in microwave histoprocesser at $850 \mathrm{w}$ for $20 \mathrm{~min}$. After cooling for $15 \mathrm{~min}$, slides were removed and washed by the washing buffer for $10 \mathrm{~min}$. The hydrogen peroxidase block was added for $10 \mathrm{~min}$, protein block was applied and incubated for $10 \mathrm{~min}$ room temperature, then washed 3 times in the PBS buffer. Diluted mouse monoclonal primary antibody at a ratio (1/50 for p53 and 1/200 for p21) was added to tissue sections and incubated 20 min primary antibody then washed 4 times in PBS buffer. Biotinylated goat anti-mouse was applied and incubated for $15 \mathrm{~min}$ in humidity chamber at room temperature after washing 4 times in PBS buffer; Streptavidin peroxi- dase was applied and incubated for $10 \mathrm{~min}$ at room temperature then rinsed 4 times in the PBS buffer. Two hundred $\mathrm{mL}$ of 3,3'Diaminobenzidine solution was and incubated $10 \mathrm{~min}$ at room temperature. Sections were minimum rinsed 4 times in the PBS buffer, then counter stain was added for 2 min at room temperature then washed in the tap water. The slides were dehydrate and mounted with DPX and coverslip, then slides were examined by light microscope $10 \times, 20 \times$ and $40 \times$. Results were compared with the positive control, which determined according to leaflet of the kit. Positivity was assessed semi quantitatively by the intensity and percentage of staining. The score was determined according to a scale when the nucleus and membrane of the cell has been stained with brown color forp53 and p21 respectively. ${ }^{18-20}$

\section{Statistical analysis}

The relationship between p53 over-expression and the clinic pathologic variables were analyzed by the Statistical Analysis System program and Chi-square test was used to significantly compare between the percentage of observed and expected frequencies. The results were considered statistically significant if the $\mathrm{P}<0.05$. $^{21}$

\section{Results}

Seventy-three bladder tumors were collected from patients. Stage and grade of each tumor were diagnosed by a consultant of histopathology according to WHO. All tumors were classified as TCC. Fourty (54.8\%) tumors were characterized by high grade and $33(45.2 \%)$ low grade while according to stage of tumors 12 (16.4\%) Ta, 28 (38.4\%) T1 invaded the subepithelial connective tissue, 22 (30.1\%) T2 invaded the muscle, 7 (9.6) T3 invaded the perivesical wall of the bladder and $4(5.5 \%) \mathrm{T} 4$ invaded other organs as shown as in Table 1.

Analysis of 73 bladder tumors and 10 biopsies of normal bladder tissues revealed that 42 (57.5\%) gave positive nuclear immune staining of p53 and $31(42.5 \%)$ gave a negative staining while all normal transitional epithelium biopsies were reflected negative immune staining as shown as in Table 2. P21 (cyclin-dependent kinases Inhibitor) suppresses tumors by promoting the cell cycle arrest in

Table 1. Classification of urinary bladder cancer patients into stage and grade.

\begin{tabular}{|c|c|c|c|c|c|c|}
\hline \multirow[t]{2}{*}{ Grade } & \multicolumn{5}{|c|}{ Stages } & \multirow[t]{2}{*}{ Total } \\
\hline & $\mathrm{Ta}$ & $\mathrm{T} 1$ & T2 & T3 & $\mathrm{T} 4$ & \\
\hline & N (\%) & N (\%) & N (\%) & $\mathrm{N}(\%$ & N (\%) & N (\%) \\
\hline Low & 12 (16.4) & $21(28.8)$ & 0 & 0 & 0 & 33 (45.2) \\
\hline High & 0 & $7(9.6)$ & $22(30.1)$ & $7(9.6)$ & $4(5.5)$ & $40(54.8)$ \\
\hline Total & $12(16.4)$ & $28(38.4)$ & $22(30.1)$ & $7(9.6)$ & $4(5.5)$ & $73(100)$ \\
\hline
\end{tabular}

Table 2. p53 and p21 expression in urinary bladder cancer and control.

\begin{tabular}{|c|c|c|c|c|c|c|}
\hline \multirow[t]{2}{*}{ Group } & \multicolumn{2}{|c|}{ p53 expression } & \multirow[t]{2}{*}{ P-value } & \multicolumn{2}{|c|}{ p21 expression } & \multirow[t]{2}{*}{ P-value } \\
\hline & $\begin{array}{c}\text { Positive } \\
\text { N }(\%)\end{array}$ & $\begin{array}{c}\text { Negative } \\
\text { N (\%) }\end{array}$ & & $\begin{array}{c}\text { Positive } \\
\text { N (\%) }\end{array}$ & $\begin{array}{c}\text { Negative } \\
\text { N (\%) }\end{array}$ & \\
\hline UBC & $42(57.5)$ & $31(42.5)$ & $0.0004 *$ & $51(69.9)$ & $22(30.1)$ & $0.0026^{*}$ \\
\hline Control & - & $10(100)$ & & - & $10(100)$ & \\
\hline
\end{tabular}

UBC, urinary bladder cancer. *Significant. 
response to cellular and environmental signals to promote tumor suppressor activities. The results showed that 51 (69.9\%) out of 73 bladder tumors gave a positive staining of $\mathrm{p} 21$ with different scores, $22(30.1 \%)$ gave negative immune staining and all ten normal urothelium consistently demonstrated no p21 immune reactivity, providing a negative staining pattern as shown in Table 2 .

The bladder tumors gave positive expression of p53 and p21 with different scores, summarized in Table 3. Positive staining of p53 with score +3 reflected a high frequency $17(23.3 \%), 15(20.5)$ for score +4 then $9(12.3 \%)$ score +2 and $1(1.4 \%)$ for score +1 while score +2 represented the highest frequency $17(23.3 \%)$ of p 21 , score +3 represented $16(22 \%)$ and score +4 represented 12 $(16.4 \%)$ while score +1 gave the lowest percentage $6(8.2 \%)$ with significant differences.

In addition, the results in Figure 1 and Table 4 showed a higher significant positive expression of p53 according to tumor stage. Results observed that invasive stages reflected strong positive immune expression of p53 and p21 when compared with non-invasive stages with significant difference. Score +3 represented the most prevalent one which expressed by tumors had invasive stages $(20.6 \%)$ followed by score $+4(17.8 \%)$ then score $+2(4.1 \%)$, no one expressed score +1 of positive expression and only $2(2.7 \%)$ gave negative expression of $\mathrm{p} 53$. Most of tumors had non-invasive stages $29(39.8 \%)$ gave negative immune staining. The results demonstrated in Figure 2 and Table 4 showed that the highest positive expression of $\mathrm{p} 21$ with score +3 and score +2 was observed among tumors had invasive stages. Moreover, the highest negative p21 expression was recorded among tumors had non-invasive stages.

Table 5 revealed that the highest significant positive expression of p53 according to tumor grade was recorded in high grade $36(85.7 \%)$ out of 42 and $6(14.3 \%)$ low grade. The highest negative expression in the low grade was 27 out of $31(87.1 \%)$ and 4 $(12.9 \%)$ in high grade as shown as in Figure 1.

The expression of the cyclin dependent kinase inhibitor p21 provides important prognostic information in patients with UCC of the bladder. Patients with tumors that maintained p21 expression demonstrated a statistically significant decreased rate of tumor recurrence and a statistically significant increased overall survival in comparison with those whose tumors had lost expression of p21 and statistically significant association between p21 expression and tumor progression was observed at all pathologic stages. The results in Table 5 revealed that a higher positive expression was recorded in high grade $29(56.9 \%)$ out of 51 and $22(43.1 \%)$ out of 51 in low grade with significant differences while the negative expression in low grade was $11(50 \%)$ out of 22 and $11(50 \%)$ in high grade Figure 2.

\section{Discussion}

TCC is one of the most common cancers in developed countries which accounts for the $90-95 \%$ of bladder carcinoma. The tumor suppressor protein $\mathrm{p} 53$ plays an essential role in human cancer, which prevents the neoplastic transformation with induction of senescence or cell death by apoptosis. Inactivation of tumor suppressor genes can occur either primarily through mutations, or without any change in the structure of the given genes. Thus, tumor suppressor function should be analyzed at the level of the genes as well as at the level of proteins, and in the context of the pathways in which these genes are involved..$^{22-24}$

In this study p53 over-expression was mainly found in advanced stage. Statistically, the over-expression of p53 in relation to stage was significant confirming the observation by, some other studies. Puzio-Kuter et al. ${ }^{25}$ reported that inactivation of $\mathrm{p} 53$ promotes tumorigenesis in human bladder and p53 wild-type (undetectable) in non-invasive papillary tumors while p53 alteration,

Table 3. Frequency of p53 and p21 scores in urinary bladder cancer.

\begin{tabular}{lcc} 
Score & $\mathrm{p} 53$ & $\mathrm{p} 21$ \\
Score 0 & $31(42.5)$ & $22(30.1)$ \\
Score +1 & $1(1.4)$ & $6(8.2)$ \\
\hline Score +2 & $9(12.3)$ & $17(23.3)$ \\
Score +3 & $17(23.3)$ & $16(22)$ \\
\hline Score +4 & $15(20.5)$ & $12(16.4)$ \\
Total & $73(100)$ & $73(100)$ \\
\hline
\end{tabular}
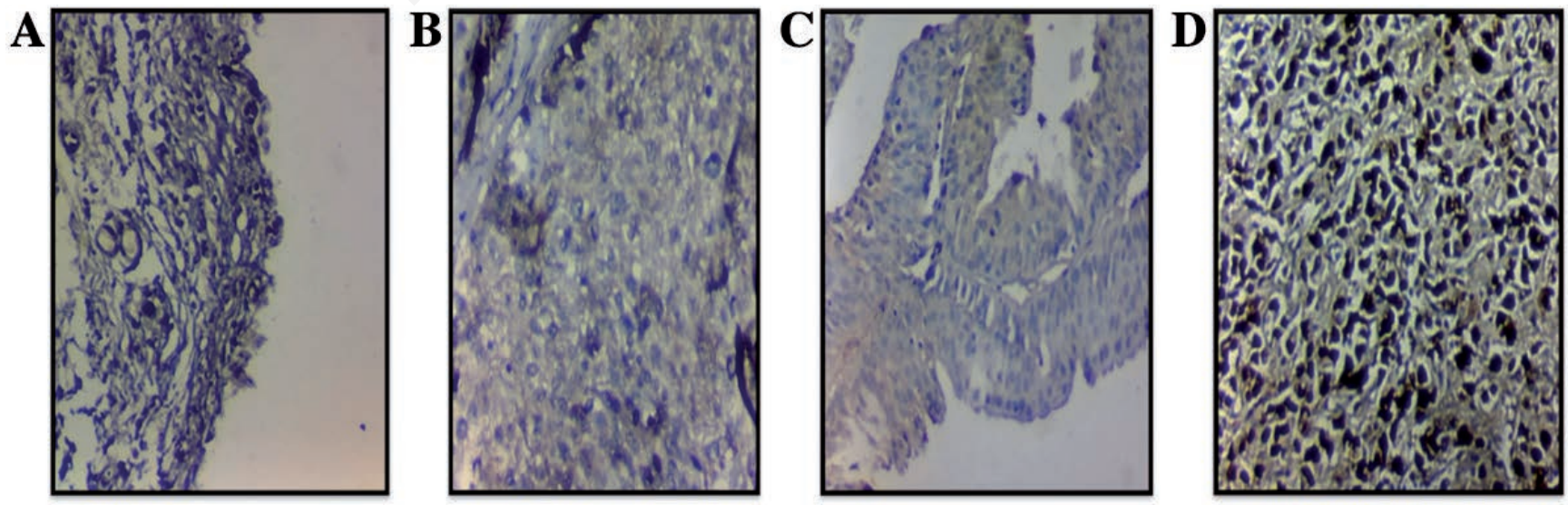

Figure 1. Immunohistochemical staining of p53. (A) Negative normal urothelium (10x). (B) Negative non-invasive transitional cell carcinoma (TCC), stage T1, low grade. (C) Negative invasive TCC, stage T3, high grade (10×). (D) Positive invasive TCC, stage T4 section under 10x. 
p53 nuclear over overexpression and/or gene mutations were frequently observed in invasive bladder tumors. On the contrary, over-expression of p53 in relation to grade was significant statistically as shown by Tawfeeq and Al-Talib ${ }^{26}$ who reported significant correlation with higher grades while over-expression of p53 in association with grade was not significant statistically as shown by others. ${ }^{27-29}$ These contradictory results might be due to sample size and the presence of inter- and intra-individual variations in evaluation of tumor grades in patients with bladder tumors and differences in staining procedure. Mutated p53 is dysfunctional and has a prolonged half-life resulting in the nuclear accumulation of the abnormal protein. Mutations in p53 gene are not the only reason for accumulation of this protein in cancer cells. Kobayashi and Tsukamoto established that p53 could be up regulated by genes, such as jun, myc and other cascade proteins in signal transduction. Studies demonstrated other tumors with non-mutational patterns of TP53 overexpression might be due to mutations in the TP53 that occurred outside exons 5-8, or to the overexpression of TP53 caused not only by TP53 mutations but also by other factors (such as MDM2) which bind to TP53 protein, thus increasing its half-life and allowing it to accumulate in the nucleus. This observation may reflect alterations in the TP53 pathway rather than in the TP53 gene itself. ${ }^{30,31}$ Results revealed that $\mathrm{p} 21$ over-expression of $\mathrm{p} 53$ in relation to stage and grade was significant. On other hand, noted by comparison that $76 \%$ of the tumors exhibited abnormal p 21 expression, some of which were stages $\mathrm{Ta}$ and $\mathrm{T} 1$, but the majority were stage $\mathrm{T} 2$ or higher. This results came in accordance with Shahrokh et al., ${ }^{32}$ who reported that altered expression of $\mathrm{p} 21$ is associated with an increased risk of bladder cancer progression and death after adjusting for the effects of pathologic stage, grade, invasion, and lymph node metastases. Alteration of p21 occurred in more than half of $\mathrm{pT} 1$ bladder tumors and remained equally frequent throughout all stages. It may be attributed to that progressive cancers accumulate p21 due to impairment of the p21-induced inhibitory pathway or mutations in the gene, resulting in the overproduction of abnormal genes. Patients with tumors that maintained p21 expression demonstrated a statistically significant decreased rate of tumor recurrence and overall survival in comparison to those whose tumors had lost expression of $\mathrm{p} 21 .{ }^{33}$

\section{Conclusions}

p53 and p21 served as useful biomarker of disease outcome for urological cancers and may help identify patients who might benefit from additional treatments and closer surveillance after cystectomy.
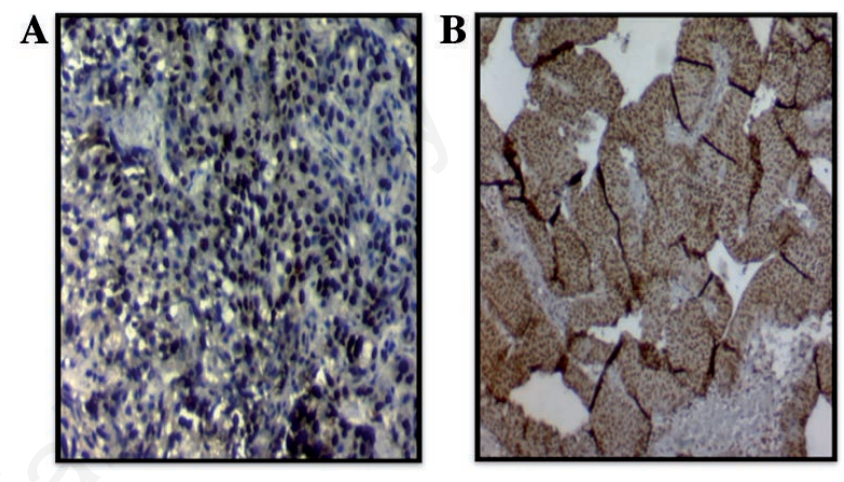

Figure 2. Immunohistochemical staining of p21. (A) Positive invasive transitional cell carcinoma (TCC), stage T2, high grade, score 4+, section under 10x. (B) Positive non-invasive TCC, stage T1, low grade, score $2+$, section under $10 \times$.

Table 4. Association between $\mathrm{p} 53$ and p21 expression with urinary bladder cancer stages.

\begin{tabular}{|c|c|c|c|c|c|c|c|c|c|c|}
\hline \multirow[t]{2}{*}{ Stages } & \multicolumn{5}{|c|}{ p53 expression score } & \multicolumn{5}{|c|}{ p21 expression score } \\
\hline & $\begin{array}{c}\text { Negative } \\
\text { N }(\%)\end{array}$ & $\begin{array}{c}+1 \\
\text { N }(\%)\end{array}$ & $\begin{array}{c}+2 \\
\mathrm{~N}(\%)\end{array}$ & $\begin{array}{c}+3 \\
\mathrm{~N}(\%)\end{array}$ & $\begin{array}{c}+4 \\
N(\%)\end{array}$ & $\begin{array}{c}\text { Negative } \\
\text { N }(\%)\end{array}$ & $\begin{array}{c}+1 \\
N(\%)\end{array}$ & $\begin{array}{c}+2 \\
\mathbf{N}(\%)\end{array}$ & $\begin{array}{c}+3 \\
\mathrm{~N}(\%)\end{array}$ & $\begin{array}{c}+4 \\
N(\%)\end{array}$ \\
\hline $\begin{array}{l}\text { Non invasive } \\
\text { (Ta-T1) }\end{array}$ & $29(39.8)$ & $2(2.7)$ & $6(8.2)$ & $2(2.7)$ & $1(1.4)$ & $13(17.9)$ & $6(8.2)$ & $7(9.6)$ & $9(12.3)$ & $5(6.8)$ \\
\hline $\begin{array}{l}\text { Invasive } \\
\text { (T2-T3-T4) }\end{array}$ & $2(2.7)$ & - & $3(4.1)$ & $15(20.6)$ & $13(17.8)$ & $9(12.3)$ & - & $9(12.3)$ & $9(12.3)$ & $6(8.2)$ \\
\hline Total & $31(42.5)$ & $2(2.7)$ & $9(12.3)$ & $17(23.3)$ & $14(19.2)$ & $22(30.2)$ & $6(8.2)$ & $16(21.9)$ & $18(24.6)$ & $11(15.1)$ \\
\hline P-value & & & $0.00537 *$ & & & & & $0.0013^{*}$ & & \\
\hline
\end{tabular}

*Significant.

Table 5. Association between $\mathrm{p} 53$ and p21 expression with urinary bladder cancer grade.

\begin{tabular}{|c|c|c|c|c|c|c|c|c|c|c|}
\hline \multirow[t]{2}{*}{ Grade } & \multicolumn{5}{|c|}{ p53 expression score } & \multicolumn{5}{|c|}{ p21 expression score } \\
\hline & $\begin{array}{c}\text { Negative } \\
\text { N }(\%)\end{array}$ & $\begin{array}{c}+1 \\
N(\%)\end{array}$ & $\begin{array}{l}+2 \\
N(\%)\end{array}$ & $\begin{array}{c}+3 \\
N(\%)\end{array}$ & $\begin{array}{c}+4 \\
N(\%)\end{array}$ & $\begin{array}{c}\text { Negative } \\
\text { N ( } \%)\end{array}$ & $\begin{array}{c}+1 \\
\text { N }(\%)\end{array}$ & $\begin{array}{c}+2 \\
N(\%)\end{array}$ & $\begin{array}{c}+3 \\
N(\%)\end{array}$ & $\begin{array}{c}+4 \\
\text { N }(\%)\end{array}$ \\
\hline Low & $27(37)$ & $2(2.7)$ & $3(4.1)$ & $1(1.4)$ & - & $11(15.1)$ & $6(8.2)$ & $5(6.8)$ & $7(9.5)$ & $4(5.5)$ \\
\hline High & $4(5.5)$ & - & $6(8.2)$ & $16(21.9)$ & $14(19.2)$ & $11(15.1)$ & - & $11(15.1)$ & $11(15.1)$ & $7(9.6)$ \\
\hline Total & $31(42.5)$ & $2(2.7)$ & $9(12.3)$ & $17(23.3)$ & $14(19.2)$ & $22(30.2)$ & $6(8.2)$ & $16(21.9)$ & $18(24.6)$ & $11(15.1)$ \\
\hline P-value & & & $0.00627^{*}$ & & & & & $0.043^{*}$ & & \\
\hline
\end{tabular}

*Significant 


\section{References}

1. Peter C, Black M, Gordon A, et al. The impact of variant histology on the outcome of bladder cancer treated with curative intent. Urol Oncol 2007;27:3-7.

2. Burger M, Catto J, Dalbagni G. Epidemiology and risk factors of urothelial bladder cancer. Eur Urol 2013;63:234-41.

3. Pesch B, Taeger D, Johnen G. Screening for bladder cancer with urinary tumor markers in chemical workers with exposure to aromatic amines. Int Arch Occup Environ Health 2014;87:715-24.

4. Khoo K, Verma C, Lane D. Drugging the p53 pathway: Understanding the route to clinical efficacy. Nat Rev Drug Discov 2014;13:217-36.

5. Lemos A, Leão M, Soares J, et al. Medicinal chemistry strategies to disrupt the p53-MDM2/MDMX Interaction. Med Res Rev 2016;36:789-844.

6. Toshinori O, Nakagawara A. Role of p53 in cell death and human cancers. Cancers 2011;3:994-1013.

7. Girardini J, Walerych D, Sal D. Cooperation of p53 mutations with other oncogenic alterations in cancer. Subcell Biochem 2014;85:41-70.

8. Grivennikov S, Florian R, Greten Y, Karin M. Immunity, inflammation, and cancer. Cell 2010;140:883-99.

9. Amaral JD, Xavier JM, Steer CJ, Rodrigues CM. The role of p53 in apoptosis. Discov Med 2010;9:145-52.

10. Hai-Bin Z, Yang K, Xie Y, et al. Silencing of mutant p53 by siRNA induces cell cycle arrest and apoptosis in human bladder cancer cells. World J Surg Oncol 2013;11:11-29.

11. Overton KW, Spencer SL, Noderer WL, et al. Basal p21 controls population heterogeneity in cycling and quiescent cell cycle states. Proc Natl Acad Sci USA 2014;111:E4386-93.

12. Parveen A, Akash MS, Rehman K, Kyunn WW. Dual role of p21 in the progression of cancer and its treatment. Crit Rev Eukaryot Gene Expr 2016;26:49-62.

13. Harper J, Adami G, Wei N, et al. The p21 Cdk-Interacting protein Cip1 is a potent inhibitor of G1 cyclin-dependent kinases. Cell 2010;75:805-16.

14. Tang K, Wang C, Chen Z, et al. Clinicopathologic and prognostic significance of p21 (Cip1/Waf1) expression in bladder cancer. Int J Clin Exp Pathol 2015;8:4999-5007.

15. McKenzie P, Danks M, Kriwacki R, Harris L. P21Waf1/Cip1 dysfunction in neuroblastoma: a novel mechanism of attenuating G0-G1 cell cycle arrest. Cancer Res 2003;63:3840-4.

16. Kausch A. Molecular aspects of bladder cancer. Eur Urol 2002;41:15-29.

17. Resnick M, Bassett J, Clark P. Management of superficial and muscle-invasive urothelial cancers of the bladder. Curr Opin Oncol 2013;2:281-8.
18. Choi J, Kim Y, Lee J, Kim Y. CD74 expression is increased in high-grade, invasive urothelial carcinoma of the bladder. Int $\mathrm{J}$ Urol 2013;20:251-5.

19. Keymoosi H, Gheytanchi E, Asgari M, et al. ALDH1 in combination with CD44 as putative cancer stem cell markers are correlated with poor prognosis in urothelial carcinoma of the urinary bladder. Asian Pac J Canc Prev 2014;15:2013-20.

20. Noroozinia F, Fahmideh A, Yekta Z, et al. Expression of CD44 and P53 in renal cell carcinoma: association with tumor subtypes. Saudi J Kidney Dis Transpl 2015;25:79-84.

21. Statistical Analysis System (SAS). User's guide. Statistical. Version 9.1th ed. N.C. USA: SAS Inst Inc Cary; 2012.

22. Loda M, Cukor B, Tam S, et al. Increased proteasome-dependent degradation of the cyclindependent kinase inhibitor P27 in aggressive colorectal carcinomas. Nature Med 1997;3:231-4.

23. Chatterjee S, George B, Goebell P, et al. Hyperphosphorylation of $\mathrm{pRb}$ : a mechanism for RB tumor suppressor pathway inactivation in bladder cancer. J Pathol 2004;203:762-70.

24. Al-Biaty H. Study of toll like receptors (TLR-2 and 4) and selected biomarkers in bladder cancer patients. Ph.D. Thesis. College of Medicine, The University of Al-Mustansiriya; 2015.

25. Puzio-Kuter AM, Castillo-Martin M, Kinkade C, et al. Inactivation of p53 and Pten promotes invasive bladder cancer. Genes Dev 2015;23:675-80.

26. Tawfeeq K, Al-Talib S. P53 over-expression in urothelial carcinoma of the bladder: an immunohistochemical study. Tikrit Med J 2013;18:198-211.

27. Barsoum H, Abd El-Hameed, Nouh M, et al. The prognostic significance of p53, Bcl-2, Cytokeratin 20 and Ki-67 in primary superficial papillary transitional bladder carcinoma. J Egypt Nat Canc Inst 2003;15:183-91.

28. Abdul-Hameed A, Muhsin M, Al-Nasiri U. The value of P53 nuclear protein expression in predicting response to intravesical mitomycin c chemotherapy. Iraqi J Med Sci 2008;6:3-14.

29. Ibrahim N, Elzagheid A, El-Hashmi H, et al. The potential value of EGFR and P53 immunostaining in tumors of the urinary bladder. Libyan J Med 2009;4:143-5.

30. Greenblatt M, Bennett W, Hollstein M, Harris C. Mutations in p53 tumor suppresser gene: clues to cancer etiology and molecular pathogenesis. Cancer Res 1994;54:4855-78.

31. Green D, Kroemer G. Cytoplasmic functions of the tumor suppressor p53. Nature 2009;458:1127-30.

32. Shahrokh F, Shariat H, Zhou J, et al. p53, p21, pRB, and p16 expression predict clinical outcome in cystectomy with bladder cancer. J Clin Oncol 2004;22:1014-24.

33. Galmozzi F, Rubagotti A, Romagnoli A, et al. Prognostic value of cell cycle regulatory proteins in muscle-infiltrating bladder cancer. J Cancer Res Clin Oncol 2006;132:757-64. 